\title{
Effects of cadmium on the behaviour of Cnesterodon decemmaculatus
}

\section{J.P. Ferro}

Programa de Ecofisiología Aplicada(PRODEA),

Departamento de Ciencias Básicas,

Universidad Nacional de Luján,

P.O. Box 221, (B6700ZBA)-Luján, Argentina

and

Instituto de Ecología y Desarrollo Sustentable (INEDES),

Universidad Nacional de Luján - CONICET,

P.O. Box 221, (B6700ZBA)-Luján, Argentina

Email: juanpferro@gmail.com

\section{L.B. Campos}

Programa de Ecofisiología Aplicada(PRODEA),

Departamento de Ciencias Básicas,

Universidad Nacional de Luján,

P.O. Box 221, (B6700ZBA)-Luján, Argentina

and

Instituto de Ecología y Desarrollo Sustentable (INEDES),

Universidad Nacional de Luján - CONICET,

P.O. Box 221, (B6700ZBA)-Luján, Argentina

Email: liriabelencampos@gmail.com

\section{N.A. Ossana, L. Ferrari and B.L. Eissa*}

Programa de Ecofisiología Aplicada(PRODEA),

Departamento de Ciencias Básicas,

Universidad Nacional de Luján,

P.O. Box 221, (B6700ZBA)-Luján, Argentina

and

Instituto de Ecología y Desarrollo Sustentable (INEDES),

Universidad Nacional de Luján - CONICET,

P.O. Box 221, (B6700ZBA)-Luján, Argentina

Fax: +54-2323-425795

Email: natyossana@gmail.com

Email: lucreciaferrari@gmail.com

Email: beteissa@yahoo.com

${ }^{*}$ Corresponding author 
Abstract: Recognising biomarkers for assessing early ecotoxicity effects using test species exposed to reference toxicants is important, hence the aim of this work was to study changes in some behavioural parameters of Cnesterodon decemmaculatus. Fish were under stress conditions induced by exposure to a subtoxic concentration of cadmium $(\mathrm{Cd})$ in the laboratory. Acute bioassays $(96 \mathrm{~h})$ were performed under laboratory conditions, with medium renewal every $48 \mathrm{~h}$. Animals were randomly assigned into two groups of 10 individuals each: Cd-exposed $\left(0.50 \mathrm{mg} \mathrm{Cd} . \mathrm{L}^{-1}\right)$ and control (moderate tap water). Both groups were video-recorded every day for $15 \mathrm{~min}$ at the same time of day. Each individual was evaluated for: a) aggressive behaviour; b) sexual behaviour; and c) swimming alterations. Fish exposed showed irregular swimming, hyperactivity periods, fewer copulation attempts and same aggressive behaviour as compared with the control group. Our results suggest that these behavioural alterations may serve as early and reliable biomarkers.

Keywords: Cnesterodon decemmaculatus; cadmium; aggressive behaviour; sexual behaviour; swimming behaviour; bioassay; video recorder; behavioural biomarkers.

Reference to this paper should be made as follows: Ferro, J.P., Campos, L.B., Ossana, N.A., Ferrari, L. and Eissa, B.L. (2019) 'Effects of cadmium on the behaviour of Cnesterodon decemmaculatus', Int. J. Environment and Health, Vol. 9, No. 4, pp.372-379.

Biographical notes: J.P. Ferro has a degree in Biological Sciences (National University of Lujan). He is $\mathrm{PhD}$ candidate and Research Fellow of the same University. His project covers the study of behavioural biomarkers in fish exposed to stressors. He is a teaching assistant in evolution for the career of biology at the National University of Lujan, Argentina.

L.B. Campos has a degree in Biotchnology at the National University of Quilmes. She is PhD candidate at the University of Buenos Aires and had a Research Fellow of National Council of Scientific and Technical Research (CONICET). She is teaching assistant in chemistry at the National University of Lujan, Argentina.

N.A. Ossana has a PhD in Biological Sciences (University of Buenos Aires). At present, she is a researcher at the National Council of Scientific and Technical Research (CONICET) and teaching assistant in physiology for the career of biology at the National University of Lujan, Argentina.

L. Ferrari has a PhD in Biological Sciences (University of Buenos Aires). At present, she is consulting Professor at the National University of Lujan, Argentina. Most of her scientific work was in the field of ecotoxicology.

B.L. Eissa graduated in Biological Sciences (University of Buenos Aires) and obtained a $\mathrm{PhD}$ at the same university. Her original research was oriented to the study of the effects of sublethal cadmium on swimming activity of freshwater teleosteans. She is a teaching assistant in chemistry at the National University of Lujan, Argentina. 


\section{Introduction}

A biomarker is defined as an observable and/or measurable change at the molecular, biochemical, cellular, physiological or behavioural level that reveals present or past exposure of an individual to a pollutant. Behavioural biomarkers in vertebrates are gaining increasing interest in aquatic ecotoxicological studies. Individuals exposed to toxicants may exhibit behaviour alterations (i.e., effect biomarkers) having potential impacts at higher levels of organisation such as the population and community levels. Fish are a good model for the study of behavioural toxicology due to their ecological relevance and because their behaviours can be easily observed and quantified. They can be found at different levels of the trophic chain and have a high morphological, physiological and ecological diversity (Dell'Omo, 2002).

Cnesterodon decemmaculatus (Poeciliidae, Cyprinodontiformes) is a South American native species widely distributed throughout the Neotropical Region including the La Plata basin where it reaches high densities in lotic and lentic water bodies of the pampean region. This species can be found from pristine to heavily degraded habitats. It is a small viviparous, micro-omnivorous, benthic-pelagic, non-migratory fish, which is easy to handle and acclimate to laboratory conditions (Ferrari et al., 2017). Due to intrinsic characteristics, such as its small size, wide range of tolerance, easy breeding in laboratory conditions it is commonly employed in bioassays to study heavy metals (Mastrangelo and Ferrari, 2013; Baudou, 2019), pesticides (Menendez-Helman et al., 2015) and contaminated river waters (Ossana et al., 2019).

Cadmium is a well-studied, non-ferrous metal of unknown physiological role which has been classified as a priority pollutant in ecosystems. The limits for surface water argentine guidelines for protection of aquatic life are 01-0.4 $\mu \mathrm{g} / \mathrm{L}$. In Argentina was found in $2 \mu \mathrm{g} / \mathrm{L}$ in Reconquista river (Rigacci et al., 2013) and $0.02 \mathrm{mg} / \mathrm{L}$ in Pilcomayo river (Casares, 2012). Alam et al. (2011) found Cd concentrations between $0-70 \mu \mathrm{g} / \mathrm{L}$ in Bangladesh wetlands.

In aquatic environments, anthropogenic activity increases $\mathrm{Cd}$ concentrations and in fish Cd may be accumulated in multiple target organs, (e.g., kidneys, liver and gills) due to its long biological half-life (Rani et al., 2014). Cadmium has toxic effects in fish, causing abnormal swimming activity in a concentration of $0.3-0.6 \mathrm{mg} / \mathrm{L}$ (Sloman et al., 2003; Eissa, 2009), alterations in gill morphology observed in $300 \mu \mathrm{g} / \mathrm{L}$ (Eissa, 2009), alterations in the energetic balance in concentration of $0.5 \mathrm{mg} / \mathrm{L}$ (Baudou, 2019), increase in antioxidant enzymes activity in Nile tilapia exposed to $0.75 \mathrm{mg} / \mathrm{L}$ (Almeida et al., 2009), and genotoxic effects in erythrocytes evaluated by micronuclei test and comet assay in a concentration of $2.0 \mathrm{mg} / \mathrm{L}$ (Ossana et al., 2019), among others. For C. decemmaculatus ecotoxicological studies, cadmium was proposed as reference toxicant, both for lethal and sub-lethal response (Mastrangelo and Ferrari, 2013). In fish, cadmium is taken up directly from the environment but may also be ingested with contaminated food. It is distributed in most tissues and accumulated in gills, liver, kidney, hepatopancreas. $\mathrm{Cd}$ in the cell is often bound to cytoplasmatic proteins (detoxifying mechanism), elimination occurs via the kidney (Rani et al., 2014).

In recent years, sexual activity has been used as a non-invasive and sensitive indicator of toxicity, with alterations in reproductive behaviour including a decrease in the intensity of sexual display and in the frequency of copulation attempts and copulation successes (Wang et al., 2014). 
It is well known that pollutants result in alterations in fish social behaviour. Sloman et al. (2002), who studied social dominance behaviour in rainbow trout exposed to copper $(30 \mu \mathrm{g} / \mathrm{L})$, observed that metal accumulation in tissues influenced their social rank. In fish, the olfactory organ is one of the first targets of pollutants, leading to impaired chemoreception and associated changes in aggression levels. Cadmium is taken up in the olfactory rosette and then moved along the olfactory nerve to finally accumulate in the olfactory bulb, thus affecting responses to natural pheromones. Non-visual sensory systems such as olfaction are undoubtedly important to successful migration (Sloman et al., 2003).

The goal of this work was to assess the effect of acute exposure to a sublethal cadmium concentration on some behavioural parameters of Cnesterodon decemmaculatus.

\section{Methods and materials}

We used fish from our stock, adults of Cnesterodon decemmaculatus. They were reared in aquaria filled with dechlorinated tap water and controlled temperature $\left(21^{\circ} \mathrm{C}\right)$ and photoperiod $(16 \mathrm{hL} / 8 \mathrm{hD})$. Then were transferred to glass aquaria to conducted the bioassay. A total of 40 animals were used, measuring $24.6 \pm 0.6 \mathrm{~mm}$ in length and $108.4 \pm 9.6 \mathrm{mg}$ in weight.

Fish used in the experiments have been cared for according to the University Bioethics Committee (Universidad Nacional de Luján, DISP SE ACAD LUJ-000143818) criteria.

Hardness, dissolved oxygen (oxymeter Hach), $\mathrm{pH}$ (pHmeter Mettler), hardness (Aquamerck test kit, sensitivity $1 \mathrm{mg} / \mathrm{L} \mathrm{CaCO}_{3}$ ) and conductivity (conductivity meter Hach) were recorded daily in each aquarium.

Cadmium solutions were prepared from a stock solution containing $1000 \mathrm{mg} \mathrm{Cd} / \mathrm{L}$ (prepared from $\mathrm{CdCl}_{2} \cdot 2.5 \mathrm{H}_{2} \mathrm{O}$, J. T. Baker, Phillipsburg, NJ, USA, in double distilled water). The effective concentration of $\mathrm{Cd}$ in the solutions assayed was measured by atomic absorption spectroscopy (Perkin Elmer, AAnalyst 200 model, quantification limit: $0.048 \pm 0.003 \mathrm{mg} / \mathrm{L})$ equipped with hollow cathode lamps $(=228.8 \mathrm{~nm})$. The calibration curve was in the range of 0.1 to $1.0 \mathrm{mg} \mathrm{Cd} / \mathrm{L}\left(y=0.167 \mathrm{x}-0.016 ; r^{2}=0.997\right)$.

Bioassays were carried out in duplicate and included two steps: a 15-d acclimation period to the experimental conditions mentioned above and a 96-h exposure to $\mathrm{CdCl}_{2}$. The aquaria media were renewed every $48 \mathrm{~h}$ over the duration of the bioassay. During the acclimation period, 10 fish were kept in each of four glass aquaria $(14 \times 14 \times 20 \mathrm{~cm})$ containing moderately hard water (MHW) with the following composition: $\mathrm{NaHCO}_{3} 96 \mathrm{mg} / \mathrm{L} ; \mathrm{CaSO}_{4 \cdot 2} \mathrm{H}_{2} \mathrm{O} 60 \mathrm{mg} / \mathrm{L} ; \mathrm{MgSO}_{4} 60 \mathrm{mg} / \mathrm{L} ; \mathrm{KCl} 4 \mathrm{mg} / \mathrm{L}$; $\mathrm{pH}, 7.4-7.8$; hardness $80-100 \mathrm{mg} \mathrm{CO}_{3} \mathrm{Ca} / \mathrm{L}$. Aquaria were placed in an incubation chamber supplied with continuous aeration, at constant temperature $\left(21 \pm 1^{\circ} \mathrm{C}\right)$ and photoperiod $(16 \mathrm{~h} \mathrm{~L} / 8 \mathrm{~h} \mathrm{D})$, and these conditions were maintained until the end of the assays. After the completion of the acclimation period, fish were separated into two groups, one of which was exposed to $0.5 \mathrm{mg} / \mathrm{L}$ of $\mathrm{CdCl}_{2}$ (nominal concentration) in MHW (exposed group-EG) and the other remained in MHW (control group-CG). At initial time, 10 fish (six females and four males) were used per replicate. Hardness, dissolved oxygen (DO), $\mathrm{pH}, \mathrm{Cd}$ concentration and conductivity were recorded daily in each aquarium. 
From each video recording the following behavioural parameters were analysed in the treated and control groups during the experimental period:

- $\quad$ swimming alterations (number of hyperactivity and loss of balance episodes)

- $\quad$ sexual behaviour (number of copulation attempts)

- $\quad$ aggressive behaviour (number of biting, fighting, chasing and tail lashing observed).

Fish were filmed daily with a digital video camera for 15-min. Behavioural assessment was performed by the Multifocal or Sweeping method, in which different observers focus on each individual of the studied groups. The first two minutes of the film were excluded to avoid potential bias in fish responses induced by the operator.

Statistical differences in aggressive behaviour, swimming alterations and sexual behaviour between the Cd-exposed and control groups were tested using the WilcoxonMann-Whitney test at the $\mathrm{p}<0.05$ significance level. Statistical analysis was carried out with Infostat software v.26.01.

\section{Results and discussion}

During the experimental period, no mortality was recorded in fish either from the control or the exposed groups.

Table 1 shows the values of water quality parameters in the aquaria of the control and exposed groups during the experimental period. Except for $\mathrm{Cd}^{2+}$ concentrations, there were no significant differences $(p>0.05)$ in the measured parameters between groups. The levels of dissolved oxygen were suitable for fish, resulting in no additional stress.

Table 1 Physicochemical parameters of the assay media. Mean $\pm \mathrm{SD} . \mathrm{ND}=$ not detected

\begin{tabular}{lcc}
\hline Parameters & Control & $0.5 \mathrm{mgCd} / \mathrm{L}$ \\
\hline $\mathrm{pH}$ & $7.36 \pm 0.4(n=8)$ & $7.44 \pm 0.22(n=7)$ \\
$\mathrm{DO}\left(\mathrm{mg} . \mathrm{L}^{-1}\right)$ & $7.62 \pm 0.4(n=6)$ & $7.52 \pm 0.8(n=8)$ \\
Conductivity $\left(\mu{\left.\mathrm{S} . \mathrm{cm}^{-1}\right)}\right)$ & $340 \pm 21(n=8)$ & $325 \pm 31(n=8)$ \\
Hardness $\left(\mathrm{mg} \mathrm{CaCO} . \mathrm{L}^{-1}\right)$ & $9 \pm 7(n=9)$ & $92.6 \pm 1(n=4)$ \\
Cadmium $\left(\mathrm{mg} . \mathrm{L}^{-1}\right)$ & & \\
Nominal $(0.50)-$ real: & $\mathrm{ND}$ & $0.46 \pm 0.03(n=4)$ \\
\hline
\end{tabular}

Cadmium-exposed fish (EG) showed a significant increase $(p<0.038)$ in the episodes of abnormal swimming (e.g., hyperactivity, loss of balance and jerky movements) (Figure 1(a)), a significant decrease $(p<0.044)$ in copulation attempts (Figure 1(b)) and same levels in aggression with respect the control group animals (CG) (e.g., biting, fighting, chasing and tail lashing) (Figure 1(c)).

Animal behaviour results from the complex interaction between an organism and its environment. Therefore, it can be used as an indicator of the individual's health status. Exposure to pollutants can induce alterations in a variety of behaviours, associated with sexuality and reproduction, activity, motivation, communication, aggression, dominance and cognitive abilities such as learning, among others (Sloman et al, 2002). Changes in habitat selection behaviour also occurs when contaminants lead organisms to avoid 
contaminated areas making them migrate to other regions, leading to an imbalance in the food chain (Araújo et al., 2018).

The inhibition of mechanosensory systems is one way through which cadmium exposure alters animal behaviour. In fish, olfactory impairment affects food search, the selection of an appropriate mate and the ability to follow migratory routes or to evaluate the risk of predation (Lürling and Scheffer, 2007). Exposure to cadmium also alters behaviours involving swimming, intraspecific interactions, predator/prey interactions, escape behaviour and avoidance responses (Scott et al., 2003; Sloman et al., 2003; Eissa, 2009).

Figure 1 (a) episodes of abnormal swimming; (b) copulation attempts and (c) aggressiveness parameters recorded in Cnesterodon decemmaculatus individuals from the control (CG) and the Cd-exposed (EG) groups. Mean $\pm \mathrm{SD}$. Asterisk indicates significant difference $(p<0.05)$ from the $\mathrm{CG}$
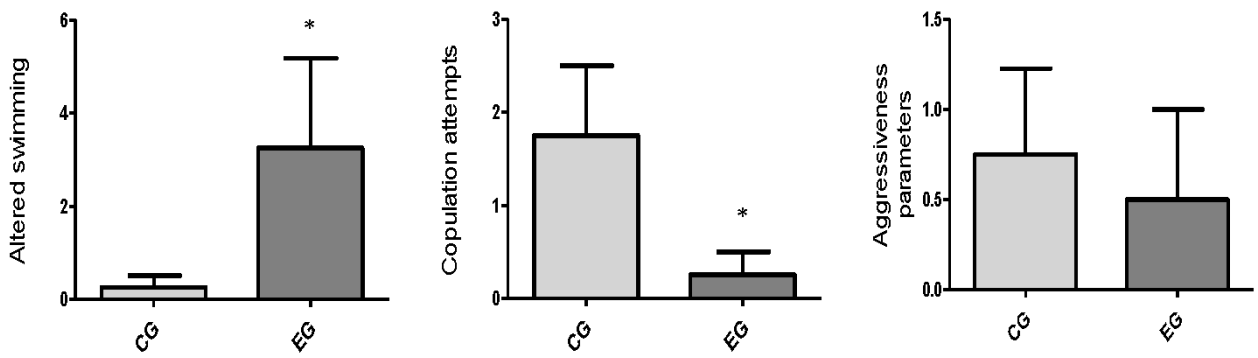

In our study, $C$. decemmaculatus individuals acutely exposed to cadmium mainly displayed hyperactivity. Alterations in swimming behaviour characterised by hypo-and hyperactivity responses resulting from sub-lethal exposure to $0.30-0.60 \mathrm{mg} \mathrm{Cd} / \mathrm{L}$ were previously observed in our laboratory in Cyprinus carpio, Australoheros facetum and Astyanax fasciatus (Eissa, 2009). Individuals of Poecilia reticulata acutely exposed to $\mathrm{CdCl}_{2}(22.5-36.0 \mathrm{mg} / \mathrm{L})$ exhibited various behavioural disorders such as imbalanced swimming, capsizing, attaching to the surface, difficulty in breathing and gathering around the ventilation filter, slowness in motion and sinking down to the bottom (Yilmaz et al., 2004). Baudou (2019) observed in C. decemmaculatus exposed to comparable Cd $(0.445 \pm 0.043 \mathrm{mg} / \mathrm{L})$ concentrations a decreased food intake and increased metabolic rate.

In the present study, acute exposure of $C$. decemmaculatus to $\mathrm{Cd}$ resulted in fewer copulation attempts. Rainbow trout exposed to $2.27 \pm 0.05 \mu \mathrm{g} / \mathrm{L} \mathrm{Cd}$ showed severely impaired social interactions (Sloman et al., 2003), while concentrations as low as $1 \mu \mathrm{g} / \mathrm{L}$ $\mathrm{Cd}$ decreased the reproductive capacity of fathead minnows (Wang et al., 2014). In fish $\mathrm{Cd}$ is a well-known endocrine disruptor due to its neuroendocrine toxicity (García-Santos et al., 2013), affecting multiple important pathways involved in reproduction and development in Oreochromis niloticus exposed to $25 \mathrm{mg} / \mathrm{L}$ of $\mathrm{CdCl}_{2}$.

We observed that the $\mathrm{Cd}$ did not induced changes in the aggressive behaviour, in the studied individuals of $C$ decemmaculatus. Other authors such as Almeida et al. (2009) observed a reduction in aggressiveness in Nile tilapia exposed to $0.75 \mathrm{mg} / \mathrm{L} \mathrm{CdCl}_{2}$ for 15 days. These behavioural responses would be due to the disruptive effect of cadmium on the olfactory system, which plays a key role in foraging and social interactions. Olfactory impairment is due to accumulation of $\mathrm{Cd}$ in the olfactory rosette, altering the fish's ability 
to respond to natural pheromones (Scott et al., 2003). The use of behavioural biomarkers in environmental monitoring studies requires the establishment of baseline levels to characterise their intrinsic natural variability (Baudou, 2019). This allows to distinguish between natural variability (noise) and the adverse effect induced by pollutants (signal).

In brief, short-term exposure of $C$. decemmaculatus to a sub-lethal concentration of $\mathrm{Cd}(0.50 \mathrm{mg} / \mathrm{L})$ induced alterations in behavioural parameters involving locomotion (i.e., increase in abnormal swimming and hyperactivity) and reproduction (i.e., fewer copulation attempts). It is worthy to mention that these responses were observed from the beginning of the experiment. The study of these parameters can be linked with apical endpoints such as: foraging, predator avoidance, reproduction, social structures and survival.

The knowledge that certain particular behavioural abnormalities are indicative of exposure to specific chemicals and their study would greatly improve the predictive capabilities of behavioural endpoints in environmental monitoring for risk assessment. The level, frequency and duration of exposure (dose) relative to the inherent sensitivity of the organism and its metabolic (detoxification) capabilities largely determine the magnitude of the resultant changes in behaviour. The initial response of fish to the exposure of contaminants is often behavioural, such as in altered habitat selection, abnormal swimming, feeding, social and reproductive behaviour. This, in turn, influences the survival, reproductive success and distribution of the individuals; and ultimately in the environmental dynamics of the population and biodiversity.

\section{Acknowledgements}

This study was supported by grants from National University of Luján, Argentina and National Agency of Science and Scientific Technology (ANPCYT PICT 2015-2636). We appreciate the input of the reviewers who gave their valuable time to help us improve our manuscript.

\section{References}

Alam, M.Z., Alib, M.P., Al-Harbic, N.A. and Choudhuryd, T.R. (2011) 'Contamination status of arsenic, lead, and cadmium of different wetland waters', Toxicological \& Environmental Chemistry, Vol. 93, No. 10, pp.1934-1945.

Almeida, J.A., Barreto, R.E., Novelli, E.L.B., Castro, F.J. and Moron, S.E. (2009) 'Oxidative stress biomarkers and aggressive behavior in fish exposed to aquatic cadmium contamination', Neotropical Ichtyology, Vol. 7, No. 1, pp.103-108.

Araújo, C.V.M., Silva, D.C.V.R., Gomes, L.E.T. and Acayaba, R.D. (2018) 'Habitat fragmentation caused by contaminants: atrazine as a chemical barrier isolating fish populations', Chemosphere, Vol. 193, pp.24-31.

Baudou, F.G. (2019) Evaluación de efectos ecofisiológicos y ecotoxicológicos en Cnesterodon decemmaculatus bajo condiciones de estrés ambiental, $\mathrm{PhD}$ Thesis, Faculty of Exact and Natural Sciences, University of Buenos Aires, Argentina.

Casares, M.V. (2012) Biodisponibilidad y toxicidad de metales pesados en aguas naturales con características fisicoquímicas extremas. Bases para su monitoreo y remediación, PhD Thesis, Faculty of Exact and Natural Sciences, University of Buenos Aires, Argentina.

Dell'Omo, G. (2002) Behavioural Ecotoxicology, Wiley, UK, 463 pages. 
Eissa, B.L. (2009) Biomarcadores comportamentales, fisiológicos y morfológicos de exposición al Cadmio en peces pampeanos, $\mathrm{PhD}$ Thesis, Faculty of Exact and Natural Sciences, University of Buenos Aires, Argentina.

Ferrari, L. (Comp.), Benitez, J., Ficella, M., Mastrángelo, M., Palacio, M., Somma, M. and Tripoli, L. (2017) Manual de procedimiento básico para la cría de Cnesterodon decemmaculatus en Laboratorio, Editorial EdUnLu, libro digital, p.49, ISBN 978-9873941-20-7.

Garcia-Santos, S., Fontaínhas-Fernandes, A., Monteiro, S.M. and Wilson, J.M. (2013) 'Effects of exposure to cadmium on some endocrine parameters in Tilapia, Oreochromis niloticus', Bulletin of Environmental Contamination and Toxicology, Vol. 90, pp.55-59.

Lürling, M. and Scheffer, M. (2007) 'Info-disruption: pollution and the transfer of chemical information between organisms', Trends in Ecology and Evolution, Vol. 22, pp.374-379.

Mastrangelo, M. and Ferrari, L. (2013) 'Cnesterodon decemmaculatus juveniles as test organism in toxicity assessment: cadmium case', Bulletin Environmental Contamination and Toxicology, Vol. 91, pp.49-54.

Menéndez-Helman, R., Ferreyroa, G.V., dos Santos Afonso, M. and Salibián, A. (2015) 'Circannual rhythms of acetylcholinesterase (AChE) activity in the freshwater fish Cnesterodon decemmaculatus', Ecotoxicology and Environmental Safety, Vol. 111, pp.236-241.

Ossana, N.A., Baudou, F.G., Castañe, P.M., Tripoli, L., Soloneski, S. and Ferrari, L. (2019) 'Histological, genotoxic, and biochemical effects on Cnesterodon decemmaculatus (Jenyns 1842) (Cyprinodontiformes, Poeciliidae): early response bioassays to assess the impact of receiving waters', Journal of Toxicology, Vol. 2019, pp.1-13.

Rani, A., Kumar, A., Lal, A. and Pant, M. (2014) 'Cellular mechanisms of cadmium-induced toxicity: a review', International Journal Environmental Health Research, Vol. 24, pp.378-399.

Rigacci, L.N., Giorgi, A.D.N., Vilches, C.S., Ossana, N.A. and Salibián, A. (2013) 'Effect of a reservoir in the water quality of the Reconquista River, Buenos Aires, Argentina', Environmental Monitoring and Assessment, Vol. 185, pp.9161-9168.

Scott, G.R., Sloman, K.A., Rouleau, C. and Wood, C.M. (2003) 'Cadmium disrupts behavioural and physiological responses to alarm substance in juvenile rainbow trout (Oncorhynchus mykiss)', Journal Experiment Biology, Vol. 206, pp.1779-1790.

Sloman, K.A., Baker, D.W., Wood, C.M. and McDonald, D.G. (2002) 'Social interactions affect physiological consequences of sublethal copper exposure in rainbow trout, Oncorynchus mykiss', Environmental Toxicology and Chemistry, Vol. 21, pp.1255-1263.

Sloman, K.A., Scott, G.R., Diao, Z., Rouleau, C., Wood, C.M. and McDonald, D.G. (2003) 'Cadmium affects the social behavior of rainbow trout, Oncorhynchus mykiss', Aquatic Toxicology, Vol. 65, pp.171-185.

Wang, Y., Ferrari, M.C.O., Hoover, Z., Yousafzai, A.M., Chivers, D.P. and Niyogi, S. (2014) 'The effects of chronic exposure to environmentally relevant levels of waterborne cadmium on reproductive capacity and behaviour in Fathead Minnows', Archives of Environmental Contamination and Toxicology, Vol. 67, No. 2, pp.181-191.

Yilmaz, M., Gul, A. and Karakose, E. (2004) 'Investigation of acute toxicity and the effect of cadmium chloride $\left(\mathrm{CdCl}_{2} \cdot \mathrm{H}_{2} \mathrm{O}\right)$ metal salt on behavior of the guppy (Poecilia reticulata)', Chemosphere, Vol. 56, pp.375-380. 